\title{
Ensuring food security: an analysis of the industrial smoking fishery sector of Ghana
}

Berchie Asiedu ${ }^{1 *}$ (D), Pierre Failler ${ }^{2}$ and Yolaine Beygens ${ }^{3}$

\begin{abstract}
Background: The smoked fishery sector of Ghana plays an important role in terms of food security, employment creation, income generation and foreign exchange earnings aiding sustainable development of the Ghanaian economy. Fish smoking is the leading technique of fish processing in Ghana (70-80\% of local fish consumption is smoked). As fish consumers are becoming more aware of fish safety issues, it is vital to analyse developments in the smoked fishery sector of Ghana in order to ensure food safety, nutritional needs, fish food security and employment. The purpose of this paper is to analyse the industrial fish smoking sector, especially, exports to the European market (Ghana's biggest customer in terms of earnings). Also, an analysis of the various characteristics and interests of fish smoking will be conducted. Managing the fishery resources through value addition and trade will help Ghana to achieve sustainable development targets.
\end{abstract}

Results: Smoked fish provides food, nutrients and livelihoods to a number of Ghanaians, especially the poor. Aside from traditional fish smoking production, about $67 \mathrm{t}$ of industrial smoked fish [in live weight (Euro stat Conversion Factor for smoked fish (into live weight) is 3.31)] is produced annually by smoking establishments, most of it going to Europe. The market for Ghanaian industrial smoked fish products is the African diaspora living in European countries and is worth $64 \mathrm{t}$ (in live weight) valued at 80,000 EUR in 2016. The major species smoked are from inland sources (mainly Chrysichthys sp., Tilapia sp., Lates sp., Synodontis sp., Hydrocynus sp., Cyprinus carpio and Clarias sp.) and marine sources (Sphyraena sp., Caranx sp., Sardinella, herrings and Penaeus sp.). Industrial smoking establishments are supplied by approved fishing establishments selected only based on EU food safety standards, by Ghanaian Competent Authority (CA). The approved smoking establishments are supplied by just a few fishing vessels supplying marine species, and mainly rely on small-scale fisheries for their raw material. Both the plant and the Competent Authority regularly monitor all stages of the production chain, the landing sites, plant structure and processing process.

Conclusions: Industrial smoked fish products have high value added. It is important to support this processing industry. Generally, the smoking industry in Ghana is characterised by up to $50 \%$ capacity utilisation. Fish waste is generally sold to livestock and aquaculture feed farms. Quality requirements of smoked products not only involve polycyclic aromatic hydrocarbons (PAHs) levels but also Listeria, histamine (for some species) and Clostridium. Further attention and support should be given to the small and medium enterprises and processing associations trying to reach the EU PAHs threshold (2 ppm/kg) by improved methods, making traditional smoking safer and directly benefiting the Ghanaian population. Moreover, the capacity of the Ministries of Fisheries and Aquaculture Development, Trade and Industry, Health, Food Research Institute, Ghana Export and Promotion Authority, Ghana Standards

\footnotetext{
*Correspondence: berchieasiedu@yahoo.com

${ }^{1}$ Department of Fisheries and Water Resources, University of Energy

and Natural Resources, P. O. Box 214, Sunyani, Ghana

Full list of author information is available at the end of the article
} 
Authority and the Food and Drugs Authority should be built to effectively monitor processing establishments in order to produce safe smoked products for European diasporas and Ghanaians.

Keywords: Fish, Ghana, Processing, Fish smoking, Food security, Quality, Small-scale fisheries

\section{Background}

Fish plays a key role in the supply of animal protein, micronutrients and essential fatty acids needs of Ghanaians. The annual per capita consumption of fish in Ghana is estimated at about $25 \mathrm{~kg}$ which is higher than the world's average of $20 \mathrm{~kg}$ [1]. Globally, fish contribute around $18 \%$ of the total animal protein intake [2]. Fish is the preferred and cheapest source of animal protein in Ghana; about $75 \%$ of the total annual catch in the country is consumed locally. Fish consumption represents $60 \%$ of animal protein intake by Ghanaians [3] which is higher than the world's average. Ghanaians prefer consuming fish in smoked form because of its flavour and delicacy (70-80\% of local fish consumption is smoked). Smoked fish products offer the lowest values of saturated fatty acids [4].

Aside it being consumed locally, some fish and fishery products are also commodities for the export business (regionally with the neighbouring countries, internationally with the European Union mainly, UK, France, Spain, and the Netherlands). Ghana is among major countries in West Africa that consume large quantities of traditional smoked fish and also export to the international markets in Europe and USA for the Diaporas [5].

Fish processing in Ghana can be broadly classified into traditional and modern. Traditional fish processing methods include smoking, drying, salting, fermenting and combinations of these while modern fish processing methods include canning and freezing [6]. Traditional fish processed products such as smoked fish, dried and salted fish are mostly patronised by the average Ghanaian due to their affordability and good taste. In Ghana, fish smoking is the most practised preservation method. Practically, all species of fish available in the country can be smoked. Fish smoking in Ghana is traditionally carried out by women in coastal towns and villages, groups/ associations, and inland fishing communities particularly along the shores of Lake Volta. This is common in most sub-Saharan African countries [7].

Traditional smoking establishments use basic facilities and equipment including smoking ovens or kilns, stainless knives, fuel-wood and plastic bags. Water used to wash fish before smoking is retrieved from public standpipes or fetched from the nearest well, river, or marine shore [8]. Most traditional smoked fish processors in Ghana operate in dusty and unsanitary environments without a good refuse disposal system $[9,10]$.
Conducted in the open or under a shelter, there is little quality control of the establishment structure and process. This puts millions of smoked fish consumers (mostly local consumers) at health risk. Furthermore, traditional smoking processors have serious health drawbacks due to the smoking technique, such as respiratory and eye illnesses, and also develop cancer susceptibility [11] due to the smoke. Smoked products also contain carcinogenic and mutagenic substances, known as polycyclic aromatic hydrocarbons (PAHs) [11-13]. These compounds are found also in food as a result of food processing techniques like drying, roasting and grilling [14]. The International Association of Food Inspectors (IAFI) published a position paper in 2017 at the World Seafood Congress 2017, evaluating the PAHs content to $32 \mathrm{ppb} / \mathrm{kg}$ in West Africa traditional smoked fishery products [25]. Therefore, these traditional products do not comply with EU food safety standards, particularly PAHs maximum residues limits [12], such as for benzo[a]pyrene $(2 \mathrm{ppb} / \mathrm{kg})$ and for the involved four PAHs $(12 \mathrm{ppb} / \mathrm{kg})$. As a result, some industrial smoking emerged in the country fulfilling this food safety needs, protecting consumer health, in order to satisfy the demand of the African population living in European countries. Fish species smoked by traditionally smoked fish processors include catfish, tilapia, sardinella, horse mackerel, tuna, and salmon.

Canned fish, usually from industrial processing, are patronised by the affluent Ghanaians. It is in this regard that some Ghanaian businesses have indeed entered into industrial fish smoking, supplying smoked fish to overseas markets and to a much lower extent in local distribution supermarkets. In 2017, only four industrial smoking plants were approved by the official Ghanaian Competent Authority to export to Europe, their main customer [15]. According to the EuroStat website,${ }^{1}$ the average production of these industrial smoking establishments over the last decade (2007-2016) is approximately $20 \mathrm{t}$ of smoked products per year (worth $67 \mathrm{t}$ in live weight ${ }^{2}$ ), bringing to the Ghanaian economy approximately 80,000 EUR per year (within the same time period). This helps to cushion the economy in sectors like infrastructure development,

\footnotetext{
${ }^{1}$ EuroStat website: http://ec.europa.eu/eurostat/data/database.

${ }^{2}$ Conversion factor of EuroStat between dry weight and live weight is 3.31 .
} 
Table 1 Summary of primary data collection methods used

\begin{tabular}{lcc}
\hline Method employed & Number of people & Targeted group \\
\hline Interview & 20 & $\begin{array}{r}\text { Fishermen, smoking workers and establishments, quality } \\
\text { control managers, Government officials, NGOs, traders, } \\
\text { Ghana Standards Authority }\end{array}$ \\
$\begin{array}{lll}\text { Validation workshop } & 63 & \text { Smoking workers and establishments, quality con- } \\
& & \text { trol managers, Government officials, NGOs, traders, } \\
\text { Standards Authority, project managers, private sector } \\
\text { development practitioners }\end{array}$ \\
Market survey & 5 & African diasporas, stores selling hot-smoked fish products
\end{tabular}

education, health, fisheries, agriculture, rural development and foreign reserves.

\section{Purpose of study}

Fish smoking plays an important role in the socio-economic development of Ghana. The overall objective of this paper is to analyse developments in the smoked fishery sector of Ghana. Specifically, trade pattern, the smoked fish chain flow, food safety importance in the smoking sector, the performance of the processing sector and value added by smoking establishments, and different commitments will be assessed. Understanding the industrial smoked fish value chain and its performance will help in identifying opportunities in the value chain that can be exploited for commercial purposes as well as helping in the preservation of Ghana's fishery resources for future generations.

\section{Research context}

This paper is structured in this way: in the section following the introduction is the methodology of the study. This is followed by an assessment of the industrial fish smoking sector including trade pattern, smoked fish chain flow, food safety importance in the smoking sector, the performance of the processing sector as well as its value addition, and level of commitments regarding quality. The paper ends with a conclusion section, highlighting recommendations.

\section{Methods}

\section{Primary data}

\section{Interview and stakeholders' workshop}

Interviews were held with stakeholders, namely fishermen, industrial fish processors, fish exporters, distributors, government institutions, policy- makers, Non-Governmental Organisations operating along the fish processing chain as well as with supporting institutions and management bodies. Tailored interviews with
20 selected stakeholders, along with field visits, were carried out in Accra and the Volta Region (Ghana), actors being involved directly in the fish smoking industry (Directors, Quality Managers, smoking workers, fishermen) fisheries management and control (see Table 1). The interview focused on the following areas: the fish smoking flow, trade pattern, the current function of the industrial smoked fish chain, its trends, and bottle-necks, the performance of the processing sector and value added by smoking establishments, capacity index, as well as various requirements. Face-toface interviews were followed by email and telephone exchanges for further clarification. Additionally, a 1-day workshop was held with 63 participants (see Table 1) involved in the fish production and processing sector, provided opportunities for stakeholders to discuss and agree with the main findings [5].

\section{Market survey}

A brief qualitative survey was carried out in five stores selling hot-smoked fish products in Brussels (Africa area), where diasporas bought their food (see Table 1). The aim was to get general information on species smoked, their packaging, prices, and country of origin.

\section{Secondary data \\ Document analysis}

Document analysis was used both to prepare the study and to complement the primary sources (i.e. interviews and workshop). A number of publications and databases produced by individuals and organisations were retrieved and analysed as secondary data sources (i.e. Eurostat, Ghana Standards Authority, Food and Drugs Authority, Ministry of Fisheries and Aquaculture Development, Fisheries Commission, West African Regional Fisheries Project, Ghana Statistical Service, Ministry of Trade and Industry, Custom Excise and Preventive Service, Food and Agricultural Organisation). 
Table 2 Exported smoked fish from Ghana to EU (dry weight)

\begin{tabular}{llllllllllll}
\hline & $\mathbf{2 0 0 7 *}$ & $\mathbf{2 0 0 8}$ & $\mathbf{2 0 0 9 *}$ & $\mathbf{2 0 1 0 ^ { * }}$ & $\mathbf{2 0 1 1 *}$ & $\mathbf{2 0 1 2}$ & $\mathbf{2 0 1 3}^{*}$ & $\mathbf{2 0 1 4}^{*}$ & $\mathbf{2 0 1 5}^{*}$ & 2016* $^{*}$ & Average \\
\hline Qty $(\mathrm{t})$ & 16 & 25 & 22.5 & 23.6 & 22.8 & 15.6 & 12.7 & 20.8 & 29.4 & 13.9 & 20.2 \\
\hline
\end{tabular}

*Estimated figures; Source: Eurostat (http://epp.eurostat.ec.europa.eu/portal/page/portal/statistics/search_database)

Table 3 Exported smoked fish from Ghana to EU (EUR)

\begin{tabular}{|c|c|c|c|c|c|c|c|c|c|c|c|}
\hline & $2007 *$ & $2008^{*}$ & $2009 *$ & $2010^{*}$ & $2011^{*}$ & $2012^{*}$ & $2013^{*}$ & $2014^{*}$ & $2015^{*}$ & $2016^{*}$ & Average \\
\hline EUR (000) & 73.862 & 77.658 & 80.653 & 74.040 & 93.599 & 61.744 & 27.447 & 64.381 & 129.023 & 57.838 & 79.024 \\
\hline
\end{tabular}

*Estimated figures; Source: Eurostat (http://epp.eurostat.ec.europa.eu/portal/page/portal/statistics/search_database)

Table 4 Production of smoked fish in some countries

\begin{tabular}{lrrrrr}
\hline Tonnes & $\mathbf{2 0 1 3}$ & $\mathbf{2 0 1 4}$ & $\mathbf{2 0 1 5}$ & $\mathbf{2 0 1 6}$ & Average \\
\hline Thailand & 3773.9 & 4298.8 & 2578.7 & 3647.0 & 3574.6 \\
Vietnam & 1987.6 & 2250.1 & 1390.1 & 1924.3 & 1888.0 \\
China & 1786.3 & 2048.7 & 1188.6 & 1722.7 & 1686.6 \\
Ghana & 12.7 & 20.8 & 29.4 & 13.3 & 19.1 \\
Philippines & 3.5 & 2.0 & & 16.6 & 7.4 \\
Senegal & & 4.2 & & 1.0 & 1.7 \\
The Gambia & 3.5 & 2.0 & 0.3 & 17.8 & 5.8 \\
Kenya & & & 0.3 & 1.2 & 0.8 \\
\hline
\end{tabular}

Italic values indicate Ghana's production figures

\section{Results and Discussion}

Analysis of developments in the industrial fish smoking sector and the way forward

\section{Trade pattern}

According to Eurostat, over the last decade, an average of $20 \mathrm{t}$ of Ghanaian smoked fish products have been exported annually (Tilapia sp. and other smoked fish ${ }^{3}$ ) to Europe (Table 2), and worth in average nearly 80,000 EUR within the same period (Table 3).

For smoked fish species, Eurostat places Ghana in the first position among the African producing countries in terms of quantity. For 20 years now, Ghana is one of the African major players in the international fish trade, and in 2015, fish exports were worth approximately US\$300 million of which US\$160,000 emerged from approved smoking establishments [16-18]. However, main producing countries of industrial smoked fish are found in most of the Asiatic continent (Table 4), that are flooding the European market.

Figure 1 represents the price per $\mathrm{kg}$ of the industrial smoked fish exported to Europe between 2013 and 2016

\footnotetext{
3 The species accounted by Eurostat were smoked Tilapia, Catfish, Pangasius sp., Silurus sp., Clarias sp., Carps sp., Nile Perch, including fillets (excluding offals) and other smoked fish including fillets (excluding salmons, mackerels, halibuts, herrings, eels and trouts).
}

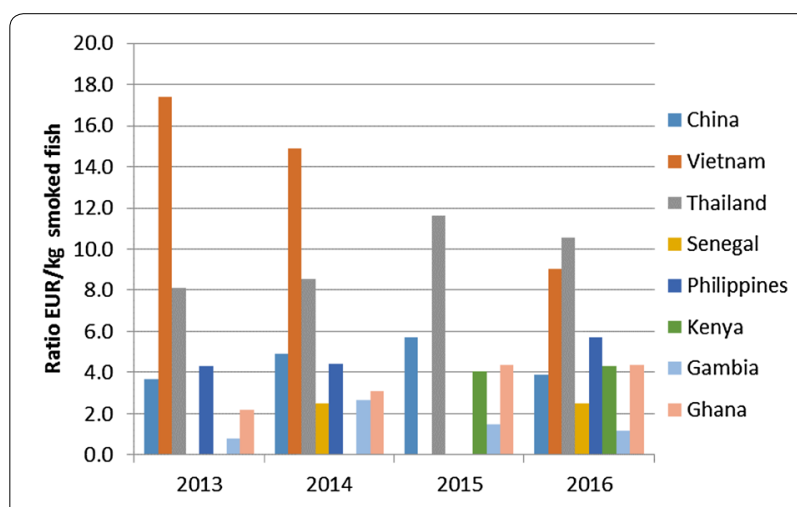

Fig. 1 Graphical representation of smoked fish price per kg exported in Europe for producing countries

for some producing countries of Africa and Asia. ${ }^{4}$ In a few cases, the shortage or absence of production in 2015 could be partly explained by the duty to comply with the new EU Regulation No 835 on PAHs of smoking establishments [12]. In Ghana, the ratio varies from 2.2 EUR/ $\mathrm{kg}$ in 2013 to $4.3 \mathrm{EUR} / \mathrm{kg}$ in 2016, increasing steadily. The other producing African countries (The Gambia, Senegal, Kenya) follow the same price pattern with a low average for The Gambia (1.5 EUR/kg), a median average in Senegal $(2.5 \mathrm{EUR} / \mathrm{kg})$ and the highest average with Ghana and Kenya (4.3 EUR/ $/ \mathrm{kg})$. A few of the Asiatic countries have the same trend as China (4.5 EUR/ $\mathrm{kg}$ ) with Philippines producing at $4.8 \mathrm{EUR} / \mathrm{kg}$. However, the largest Asiatic producers of smoked fish exported to Europe are Thailand and Vietnam, the average price per $\mathrm{kg}$ reach 9.7 EUR/kg and $13.8 \mathrm{EUR} / \mathrm{kg}$, respectively. Such a difference in price is primarily to be related to the various fish species (e.g. tilapias and catfish in Africa, and carps and Pangasius in Asia). The Asiatic countries produced highvalued smoked fish compared to African countries.

\footnotetext{
${ }^{4}$ In both continents, smoked and dried fish are often produced by the same establishment and may have been mixed up in reports at the EU border.
} 


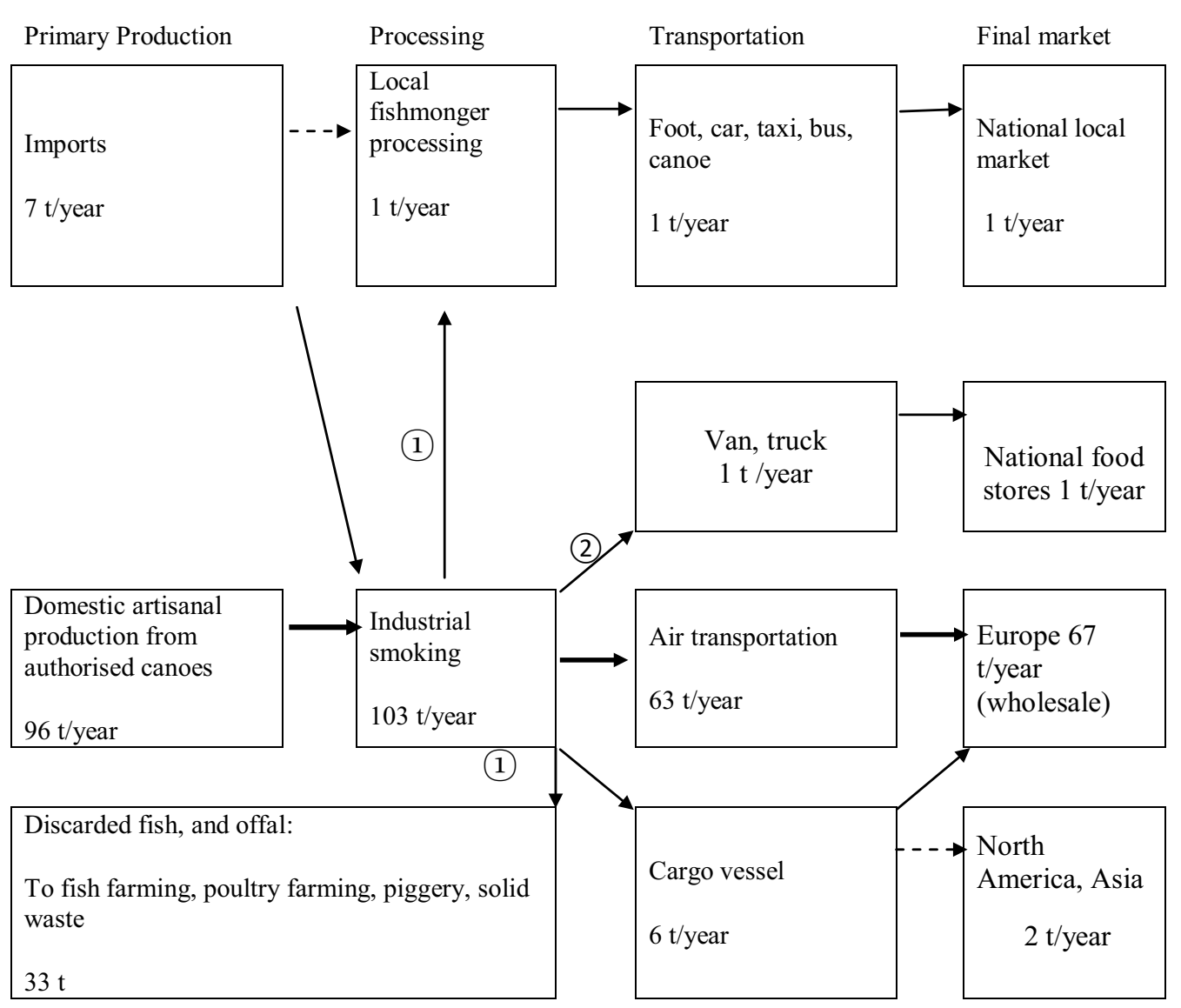

\section{Caption:}

$\longrightarrow \quad$ Main route from Ghana to Europe

$\longrightarrow \quad$ Another route for the next destination

(1) First check performed by the smoking establishment all through the processing

(2) Choice operated by establishment (national food stores order, distribution)

Fig. 2 Smoked fish processing value chain (live weight) [Euro stat Conversion Factor for smoked fish (into live weight) is 3.31 [33]] and product flows estimation

\section{Smoked fish processing chain}

A quick overview of the Ghanaian industrial fish smoking industry for average production (20.2 $\mathrm{t}$ smoked products) between 2007 and 2016 is presented in Fig. 2. Figure 2, expressed entirely in live weight (wet weight), reflects the industrial smoked fish value chain flow through (1: raw material; 2: processing; 3: transportation and 4: final market).
For the raw material, processing plants buy fresh fish from authorised small-scale canoes and to a lesser extent, from approved inshore vessels, to export to international market. In lean fishing season, processing establishment may also acquire fish from imports (i.e. frozen sardinella) to process them.

Before the processing can start, the processing establishment carries on own-checks (organoleptic and 
temperature checks) to verify the fish quality. Additionally, processing plant must have authorisation from Competent Authority inspectors, checking the quality, before they can actually start. Some fish supplied may be discarded for not being fresh enough to reach the exporting market and are directed to artisanal processing for local markets or alternatively, some other waste disposal practices for fish waste (fish farming, poultry farming, piggery, or solid waste). Increase in spoilage bacteria number is triggered by factors such bad storage conditions, crosscontamination, and ambient temperature that may have affected the raw material, thereby lowering the quality of the fish, and processors revenue [19]. During processing and just before distribution, own-checks are performed by the smoking plant, as well as those of the Competent Authority inspectors. Inspectors also check and sample the final product.

Transport to the market is the third stage. Industrial smoking companies are mainly geared towards Europe, but also to a minor extent, North America, and Asia. While a small fraction of the industrial smoked fish production is ordered by Ghanaian supermarkets, smoking products are mainly transported by air freight to Europe and reach the other destination market by cargo vessels. Traditional smoking processors use local means of transport (taxis, bus, truck, and canoe) to be sold on national or regional markets.

In respect of final international markets, approved smoking establishments contract agreements with wholesalers, then the latter will sell the fish to retailers, and the retailer to end consumer. In the study conducted by [20], in most cases, importers of smoked fish were selling directly to retailers or even have a grocery themselves.

\section{Food safety in Ghanaian industrial fish smoking}

International markets require that all imported food must abide by their food safety standards. ${ }^{5}$ The approved country of origin must have an authorised Competent Authority that could be a public or private institution, responsible to undertake official controls over the food production chain and be able to grant a reliable Health Certificate to outgoing food products. The Competent Authority (in the case of Ghana is the Ghana Standards Authority) must also approve the processing plant, guaranteeing structure and ensures that processes are in conformity with exporting country food regulations and monitor the establishment. The Competent Authority and the establishment are also in charge of verifying the food quality of processed products through analysis. Further details of the central role of the Competent

\footnotetext{
${ }_{5}$ https://ec.europa.eu/food/sites/food/files/safety/docs/ia_trade_impor t-cond-fish_en.pdf (Accessed 12 March 2018).
}

Authority in the food safety control of the industrial exporting fish industry are explained in various articles [21, 22]. Ghana's Competent Authority has the capacity and technical know-how to undertake checks on smoked fish to meet the international standards. The Ghana Standards Authority is a large statutory body in charge of the national quality infrastructure embracing metrology, standards and conformity assessment (certification, inspections and testing). The GSA is expected to become a model of excellence in standardisation in Africa [21]. This will help Ghana and other African countries to export to the EU, thereby deriving maximum benefits from fish trade.

In Ghana's industrial fish smoking case, the raw material and smoked products are tested by organoleptic test and laboratory analysis (polycyclic aromatic hydrocarbons or (PAHs), Listeria and Clostridium, histamine [12, 23, 24].

Since the PAH content is too high (around $32 \mathrm{ppb} /$ $\mathrm{kg}$ ) in traditional smoked fish in West Africa, it can no longer be exported to Europe [12, 25]. In the same way, exporting smoked products to neighbouring countries by industrial smoking establishments (producing a smoked fish below $2 \mathrm{ppb} / \mathrm{kg}$ of benzo-a-pyrene and $12 \mathrm{ppb} / \mathrm{kg}$ of $\mathrm{PAH} 4)$ does not meet the market requirements in terms of taste: other African countries would still prefer the traditional smoked fish. Fish consumers taste is difficult to change which can affect demand and supply, irrespective of the quality and nutritional value of the fish species.

To produce smoked products that meet European requirements, an industrial smoking plant needs expensive equipment and materials such as smoking device, dryers, chilled storage room, stainless steel material as to be operated in proper premises. Water in the plant originates from a source, regularly controlled by public authorities.

\section{Selected canoes for the small-scale fisheries}

The contribution of the small-scale fisheries to the industrial smoked fish value chain cannot be underestimated. Smoked fish value chain starts from small-scale fisheries since smoking establishments buy their fish from selected local fishermen (authorised suppliers). Annually, about $96 \mathrm{t}$ of fresh fish is supplied by the small-scale fisheries sector for industrial fish smoking. Each authorised smallscale fisherman has to be selected by establishments on the basis of their reputation as fishermen, their use of some good hygienic practices when fishing, landing the fish and handling. The fishermen must have their municipal health card in order, giving proof of their good health. Those fishermen have to possess a canoe in a good state of repair and maintenance (authorised canoe). The fishermen have to be registered by the Fisheries Commission, 
in this case, their activities can be regulated and monitored. This can be a mechanism of ensuring good fishing practices as well as checking illegal, unreported and unregulated (IUU) fishing practices that affect the sustainability of the fishery resources, the ecosystem and biodiversity [26]. It is estimated that IUU cost about 2.3 billion USD in revenue annually to West Africa countries including Ghana [27]. This also poses threat to food security, health of stocks $[1,28]$ and has socio-economic consequences (poverty, crime, unemployment, insecurity).

Fishermen are trained by establishments in additional Good Hygiene Practices when fishing and landing the fish (on-site) complying with all regulations. Special attention is given to proper icing methodology with clean flake ice. The process of fishermen training includes a visit to the smoking plant to familiarise themselves with the process and what the fish establishments are looking for (species, freshness and smoking process). Authorised fishermen are given ice-boxes by smoking establishments and are taught how to clean them with approved detergent and disinfectant. Most of the time, establishments supply authorised fishermen with some clean ice from the plant. Icing preserves the raw fish quality [29].

The choice of landing location where the authorised canoe is berthed is also important. It should be in line with European Regulations [21]. It is fundamental that the landing location is well kept and clean by the fishing community/Beach Fisheries Committee Management and away from any source of contamination (dumping area, animals, and unhygienic practices on the landing site). Latrines should be provided. Electricity supply should be available throughout the day when smoking establishments have refrigerator and/or freezing equipment to keep fish in good condition.

In general, establishments are dependent on the requests from their client. Fish that are most commonly asked for are:

- Inland origin: Chrysichthys sp., Tilapia sp., Lates sp., Synodontis sp., Hydrocynus sp., Carpio sp. and Clarias sp.

- Marine origin: Sphyraena sp., Caranx sp., Sardinella, Herrings, Penaeus sp.

Concerning inspections of authorised canoes and landing sites, CA inspectors have set up a landing site monitoring schedule on six major landing sites (marine and inland), at the frequency of three times a year. Smoking establishments are in charge of transporting the fish from the landing site to the processing site in a refrigerated van. It represents a cost for smoking establishments which are located some distance from the landing site.
Table 5 Value addition in industrial fish smoking industry

\begin{tabular}{|c|c|c|c|}
\hline & Quantity (kg) & $\begin{array}{l}\text { Unit price } \\
\text { (EUR) }\end{array}$ & Value (EUR) \\
\hline Value of production & 103,000 & 2 & 206,000 \\
\hline Value of processing & 21,450 & 12 & 257,400 \\
\hline Value added & \multicolumn{3}{|c|}{$(206,000+257,400) \times .40=185,360$ EUR } \\
\hline
\end{tabular}

\section{Performance of the processing industry and value added by smoking establishments}

The industrial approved fish smoking industry is characterised by a high level of additional value between fresh fish and smoked products.

The price of raw fish from fishermen in Ghana is 2 $\mathrm{EUR} / \mathrm{kg}$, and the price of finished products for export is $12 \mathrm{EUR} / \mathrm{kg}$ (Table 5). This is a high value added that is generated since other intermediate consumptions do not amount to more than $3 \mathrm{EUR} / \mathrm{kg}$. Industrial equipment needed to process the fish is around 300,000 EUR. A survey in a major commercial street selling smoked fish in Brussels conducted in March 2014 (African area) gave an average price of smoked fish sold by retailers as $30 \mathrm{EUR} / \mathrm{kg}$. ${ }^{6}$ The price of the fish is multiplied by 15 from the landing site to the end retailer in Europe. Thus, the smoked processing can be used as an avenue to create employment and generate income, especially for the youth. Over the years, the Government of Ghana has embarked on a number of initiatives (example: Youth Enterprise Support Programme, Youth in Agriculture and the Nation Builders Corps, Planting for Food and Jobs, etc.) to tackle unemployment without seriously considering fish smoking as one of the best options.

Smoked fish production capacity The current capacity of the smoking industry is presented in Table 6. The industrial smoking establishments have larger equipment than necessary (up to 50\% capacity utilisation). The year 2013 has not been a good year in terms of exports. The smoking industry is relying on high cost equipment. They work on the order, intensively and they rely on casual workers. Their storage is filled in, but they do not keep fish too long in case there is a shortage of electricity. Smoked fish is cooled down and then packaged in labelled cardboard boxes with brown paper.

\section{Level of commitments regarding quality}

Producers keep up with any changes CA inspectors request in terms of quality. The last change they had to overcome is to trace the fish down to the landing site.

\footnotetext{
${ }^{6}$ Five shops selling smoked products of different fish species were visited.
} 
Table 6 Capacity index of smoking industry

\begin{tabular}{ll}
\hline Parameters & Performance \\
\hline Capacity utilisation & Up to $50 \%$ \\
Storage & $120 \mathrm{~m}^{3}$ \\
Logistics and marketing & Can easily be contacted by phone, email and a few, websites \\
& Are easily found on Internet as partners of some projects \\
Labour productivity & Up to 1.3 t/person/year \\
Technology and processes & High technology equipment (bought in Europe, North America) in most cases composed of: \\
& Dryer \\
& Smoker \\
Chiller & Selling the waste to various farms (piggery, poultry and fish) to mix their food \\
Waste material utilisation & Depending on species, and on the order of the client: either whole or sliced, gutted some- \\
Products quality & times light brown to dark colour \\
& Packaging in brown soft paper, and in boxes, labelled with the approved number \\
\hline
\end{tabular}

Women are the most active personnel at the smoking plant. They earn income to support their families. Smoking plants usually deal with offal and have a good waste disposal practice as are they have an agreement with livestock and feed farms. This is an effective way to support the aquaculture development in the country which is contributing to fish production (around 11\% per annum) [30].

Quality in the smoked processing industry cannot be compromised. Quality control helps to reduce the occurrence of food borne diseases throughout the fish chain, from farm/capture to table [11]. Importers are consistent with the quality required by European standards but end buyers do not necessarily know. Whereas importers are interested in a good price, they also look at experienced suppliers that produce good smoked fish that meet the demand. Few importers are concerned about the environment. End buyers, mostly African Diaspora population (and some Asian population) are longing for the smoked product, coming from their region or country. Aside from this, consumers are becoming more aware that fish and fishery products can be a healthy alternative to meat from farm animals [2].

\section{Employment}

Smoking industry including the small-scale fisheries sector in the production chain provides employment to selected artisanal fishermen as well as to processing specialists (educated Quality Managers, Operation Manager) and workers. This employment helps to earn a living to an average of 4.4 household-members, including contribution to education, rent, medical fees, and food, and at the same time, to all the community. Similarly, it is offering jobs to the rural (49.1\%) and the urban (50.9\%) areas [31]. In 2014, the largest fish smoking establishment gave employment to 90 people, divided into 20 authorised fishermen, 40 processing workers, 20 people upstream and 10 people downstream [5].

While permanent workers have job security and can plan the life on the long-term, casual workers are working on orders and hence are able to defray short and medium term services.

A key role is held by women in the fish chain, as they represent $40 \%$ of stakeholders. While the gender ratio, in favour of women, is about 80/20 in handling and grading, distribution, and processing subsectors and 60/40 in quality control and marketing subsector, men were predominant in the production subsector at 70/30.

Trained personal by smoking establishments increase their knowledge, enabling them to raise awareness of their colleagues, beach community and association members, as well as friends. It gives them a higher rank in their community.

\section{Fish trade}

Fish is an important component of Ghana's economy and trade since Ghana is both a fish exporting and importing nation. Fish has become one of the important non-traditional export (NTE) products. Ghana is a net importer of fish, and the country is about $43 \%$ fish self sufficiency [30]. Annually, about $7 \mathrm{t}$ of fish is imported for processing by industrial smoking firms. In 2015, Ghana's fish exports were worth approximately US\$ 300 million of which US\$ 160,000 emerged from approved smoking establishments. The Asiatic countries (mainly China, Philippines Thailand and Vietnam) are taking the lead in smoked fish export to the EU thereby deriving maximum benefits from the fish trade business. Almost all West African fishing grounds are either fully exploited or overexploited [32]. If the Asiatic countries managed their fishing grounds properly, then they will have more stocks to harvest, smoked and export. This will adversely affect 
the smoked fish trade and food security situation in West Africa in, particularly Ghana. Already, Africa has the lowest fish per capita consumption in the world (around $10 \mathrm{~kg} /$ year) [1] and food in-secure. The only comparative advantage that Ghana and other West African countries have is cheap labour. The Government of Ghana should encourage foreign investors to invest in the smoked fish business to realise the needed benefits.

\section{Economic performance}

According to the survey of the approved smoked fish industry in Ghana undertaken in 2014, few essential characteristics emerge [5].

Ghanaian fish smoking industry falls into the small and medium enterprises, in general family owned, and cover a very small part of the market, though extremely important for the African diaspora living in European countries, ${ }^{7}$ longing for African-made smoked fish products.

The fish smoking industry is characterised by a high level of additional value between fresh fish in Ghana (average price $1 \mathrm{EUR} / \mathrm{kg}$ ) and smoked product selling net price to European importers (approximately $3.5 \mathrm{EUR} / \mathrm{kg}$ ). Therefore, each kilogram of smoked fish product generated about a value added of 1.5 euro as the difference between the revenue per kilo and the intermediate consumption, ${ }^{8}$ respectively, 3.5 and 2 EUR).

Smoking establishments operated high technology equipment bought from the USA or Europe. These were larger than necessary, and consequently, the industry was approximately worth $50 \%$ capacity of utilisation. These industrial equipment, costly to buy and maintain, comprised at least a dryer, a smoker (or a combination of both), a chill storage as well as an in-house laboratory to undertake some microbiology analysis (own-checks). The chill storage $\left(120 \mathrm{~m}^{3}\right.$ per establishment) was only filled in several subsequent orders. Although enterprises possess gasoline generator for equipment processing, they fear the shortage of electricity because of the gasoline cost. Between 2012 and 2016, Ghana experienced severe nationwide energy crisis that affected most fish smoking establishments and other sectors of the economy. Smoking enterprises usually work on the order and intensively, recruiting casual workers to complete the main staff. The labour productivity of the smoking establishment was evaluated at 1.3 tonne/person/year.

The operating costs of smoking establishments are not only salaries and wages of workers but mainly linked with food safety requirements compliance, such as specific smoking equipment purchase and maintenance (plus

\footnotetext{
${ }^{7}$ http://belgium.iom.int/activities (Accessed the 18 March 2018).

8 The intermediate consumption is mostly composed of transport fee.
}

transport and installation costs), laboratory analysis cost and Competent Authority-related expenditures. Consequently, smoking enterprises often meet financial difficulties to sustain their fish smoking business. As a result, they diversify their offer in dried fish, salted dry fish, salted smoked fish and smoked agricultural products.

A brief telephone survey was undertaken in Brussels in 2018 at an intermediate wholesaler regarding smoked fish origin, species and price, providing retailers for African Diaspora. The bulk of the arrival came from re-export of another European country, or directly from developing countries. Smoked fish species were catfish, mackerel, lizard fish, barracuda rings, herrings, and bonga shad. The price of smoked fish ranged from $27 \mathrm{EUR} / 4 \mathrm{~kg}$ for catfish, $36 \mathrm{~kg} / 5 \mathrm{~kg}$ for barracuda rings with frozen smoked mackerel at $18 \mathrm{EUR} / 4 \mathrm{~kg}, 36.9 \mathrm{EUR} / 5 \mathrm{~kg}$ (lizard fish), excluding Value Added Taxes.

Diasporas normally buy smoked fish from the retailers direct, themselves purchasing at the intermediate wholesalers. In the brief market study in 2014 carried out at five retailers stores in Brussels, the average price of smoked fish was $12 \mathrm{EUR} / \mathrm{kg}$, but the African origin was not common (5 on 27 samples: 18.5\%). No fish came from Ghana on the day sampling was undertaken. The bulk of the products are sourced from Asia (mainly Thailand China and Vietnam).

\section{Environmental performance}

Environmental characteristics have to be taken into account in setting the establishment, so as to ensure food safety. The supply of clean water at premises, equipment and materials and also fish has to be issued from a controlled distribution system. At the smoking plant, producers are conducting good waste disposal practices (e.g., small fish farming, livestock farms as a feed supplement). This is an effective way to support aquaculture development in the country, which is contributing to fish production (around 11\% per annum) [30].

\section{Conclusion and recommendations}

Smoked products from inland and marine sources $(67 \mathrm{t} /$ year) continue to provide food security and nutritional needs of many Ghanaians. The industrial smoke products are geared towards the export market, which must comply with high standards. It would be worthwhile to support this processing industry. Usually, in terms of performance, the smoking industry in Ghana is characterised by up to $50 \%$ capacity utilisation using high technology such as dryers, chillers, and smokers. Quality requirements of smoked products are not only PAHs level but also Listeria, histamine (for some species) and Clostridium. CA inspectors must check both raw material and processed products and also sample them for 
official controls. To meet the European Commission requirement on the very low level of carcinogenic PAHs, companies have to invest in expensive equipment based on the separation of the drying and smoking phase and/ or on indirect smoking. Notwithstanding the expense of the equipment, establishments also have to bear with costly tests.

Discarded fish species by industrial establishments are directed to the artisanal processing sector for the local markets. Fish waste is used to support fish farming, poultry, piggery and solid waste, thereby ensuring better use of the fishery resources.

The means of transportation is through local transport (taxis, bus, truck, and canoe), cargo vessels with air transport being the highest. Thus, the final product is geared towards the export market, namely Asia, North America and Europe.

\section{Recommendations}

The following is recommended to improve the industrial smoked fishery sector of Ghana:

- The Government of Ghana through the responsible ministries and agencies, namely Fisheries, Trade and Industry and Export Promotion Authority, should work strongly with fish processors so that they can meet the requirements of the international market for smoked fish. This will help gain trade benefits which will go a long way to sustain the Ghanaian economy.

- The capacity of the relevant monitoring institutions, namely Ministries of Fisheries and Aquaculture Development, Trade and Industry, Ghana Standards Authority and the Food and Drugs Authority, should be improved urgently to effectively monitor processing establishments in order to produce safe smoked products to meet food security and nutritional needs of Ghanaians and diasporans.

\section{Abbreviations \\ EU: European Union; EUR: Euro; PAHs: polycyclic aromatic hydrocarbons; $t$ : tonnes.}

\section{Authors' contributions}

BA was responsible for conceptualising, sourcing of the literature, data analysis, and writing of the manuscript. PF participated in sourcing of the literature and writing of the manuscript. YB participated in sourcing of the literature, data collection at Brussels commercial streets, and writing of the manuscript. All authors read and approved the final manuscript.

\section{Author details}

${ }^{1}$ Department of Fisheries and Water Resources, University of Energy and Natural Resources, P. O. Box 214, Sunyani, Ghana. ${ }^{2}$ Economics and Finance Group, Portsmouth Business School, University of Portsmouth, Richmond Building, Portland Street, Portsmouth PO1 3DE, UK. ${ }^{3}$ Fish Quality Independent Consultant, Dieweg 30A, 1180 Brussels, Belgium.

\section{Acknowledgements}

We thank all processors, shop owners, government agencies, and institutions who assisted us with data. The contributions of the anonymous reviewers are acknowledged.

\section{Competing interests}

The authors declare that they have no competing interests.

\section{Availability of data and materials \\ Not applicable.}

\section{Consent for publication}

Not applicable.

Ethics approval and consent to participate

Not applicable.

\section{Funding}

This work was supported by the UNIDO/MOTI Trade Capacity Building Programme for Ghana US/GH/06/005.

\section{Publisher's Note}

Springer Nature remains neutral with regard to jurisdictional claims in published maps and institutional affiliations.

Received: 15 August 2017 Accepted: 22 May 2018

Published online: 08 June 2018

\section{References}

1. FAO. The State of World Fisheries and Aquaculture 2016. Contributing to food security and nutrition for all. Rome: FAO; 2016.

2. FAO. The future of food and agriculture - trends and challenges. Rome: FAO; 2017

3. Sarpong DB, Quaatey NK, Harvey SK. The Economic and social contribution of fisheries to gross domestic product and rural development in Ghana. FAO Sustainable Fisheries Livelihoods Programme (SFLP) GCP/ INT/735/UK. 2005.

4. Akintola SL, Brown A, Abdullahi B, Osowo OD, Bello BO. Effects of hot smoking and sun drying processes on nutritional composition of giant tiger shrimp (Penaeus monodon, Fabricius, 1798). Pol J Food Nutr Sci. 2013;63(4):227-37.

5. Failler $P, A$ Asiedu $B$, Beyens $Y$. Value chain analysis of the fishery sector in Ghana with focus on quality, environmental, social, sustainable, food safety, organic requirements and its compliance in infrastructure. United Nations Industrial Development Organization Trade Capacity Building for Ghana Project. 2014. https://doi.org/10.13140/rg.2.1.2421.5201.

6. Nunoo FKE, Asiedu B, Kombat EO, Samey B. Sardinella and other small pelagic value and supply chain of the fishery sector, Ghana. The USAID/ Ghana Sustainable Fisheries Management Project (SFMP). Narragansett, Rl: Coastal Resources Center, Graduate School of Oceanography, University of Rhode Island and Netherlands Development Organisation. GH2014_ACT044_SNV. 2015. http://www.crc.uri.edu/download/GH201 4_ACT044_SNV_FIN508.pdf.

7. Ahmed A, Dodo A, Bouba AM, Clement S, Dzudie T. Influence of traditional drying and smoke-drying on the quality of three fish species (Tilapia nilotica, Silurus glanis and Arius parkii) from Lagdo Lake, Cameroon. J Anim Vet Adv. 2011;10(3):301-6.

8. Axtell B, Fellows PJ. Setting up and running a small meat or fish processing enterprise. Opportunities in food processing series Wageningen: ACP-EU Technical Centre for Agricultural and Rural Cooperation (CTA). 2003. ISBN 92-9081-275-3.

9. Doe J. An analysis of quality control of smoked fish business in the Sunyani Municipality. B.Sc. thesis, University of Energy \& Natural Resources, Sunyani, Ghana. 2017.

10. Kogbe M. Microbial and heavy metal contamination of skipjack and yellowfin tuna from beaches in the Greater Accra Region. M.Sc. thesis, Department of Theoretical and Applied Biology, Kwame Nkrumah University of Science and Technology. 2015. 
11. FAO. Food safety policies and regulatory frameworks. Rome: FAO; 2009. p. 19.

12. EC. Commission Regulation (EU) No. 835/2011 of 19 August 2011 amending Regulation (EC) No. 1881/2006 as regards maximum levels for polycyclic aromatic hydrocarbons in foodstuffs. 2011.

13. Simko P. Determination of polycyclic aromatic hydrocarbons in smoked meat products and smoke flavouring food additives. J Chromatogr B. 2002;770(1-2):3-18.

14. Palm LMN, Carboo D, Yeboah PO, Quasie WJ, Gorleku MA, Darko A. Characterization of polycyclic aromatic hydrocarbons (PAHs) present in smoked fish from Ghana. Adv J Food Sci Technol. 2011;3(5):332-8.

15. FVO. Approved establishments in Ghana, Fishery products. Validity 00061. 17 July 2017. 2017.

16. Asiedu B, Failler P, Beyens $Y$. The performance of tuna processing fishery sector to sustainable fish trade and food security in Ghana. J Energy Nat Resource Manage. 2015;2(1):8-14.

17. EC. Commission Decision (EC) No 98/421/EC laying down the conditions of fishery products imports from Ghana. p. 5. 1998. http://eur-lex.europ a.eu/legal-content/EN/TXT/PDF/?uri=CELEX:31998D0421\&from =FR.

18. Ministry of Fisheries and Aquaculture Development (MoFAD). 2015 Annual report. MoFAD, Accra. p. 78. 2016.

19. Valtysdottir KL, Margeirsson B, Margeirsson B, Lauzon HL, Martinsdottir E. Guidelines for precooling of fresh fish during processing and choice of packaging with respect to temperature control in cold chains. Technical report 40-10, Matís, Reykjavík, Iceland. 2010. http://www.matis.is/media/ matis/utgafa/40-10-Guidelines-for-precooling-and-packaging.pdf.

20. Ward A. A study of the trade in smoked-dried fish from West Africa to the United Kingdom. FAO Fisheries Circular No. 981, Rome, FAO, p. 17. 2003.

21. Beyens $Y$, Failler $P$, Asiedu B. Institutional challenges and constraints for Ghana in exporting fishery products to the European Union. Food Rev Int. 2018;34(3):265-89.

22. Neeliah S, Goburdhun D. National food control systems: a review. Food Rev Int. 2007;23(1):35-51.

23. EC. Commission Regulation (EC) No. 1881/2006 of 19 December 2006 setting maximum levels for certain contaminants in foodstuffs. 2006.
24. EC. Commission Regulation (EU) No. 1019/2013 of 23 October 2013 amending Annex I to Regulation (EC) No. 2073/2005 as regards histamine in fishery products. 2013

25. IAFI. Statement from the International Association of Fish Inspectors on the safety of smoked fishery products. Position paper, relating particularly to polycyclic aromatic hydrocarbons. World Seafood Congress, Reykiavik, Iceland. 10-13 Sept 2017. 2017.

26. Pauly D, Christensen V, Guenette S, Pitcher T, Sumaila UR, Walters $C$, Watson R, Zeller D. Toward sustainability in world fisheries. Nature. 2002;418:689-95

27. Doumbouya A, Camara OT, Mamie J, Intchama JF, Jarra A, Ceesay S, Guèye A, Ndiaye D, Beibou E, Padilla A, Belhabib D. Assessing the effectiveness of monitoring control and surveillance of illegal fishing: the case of West Africa. Front Mar Sci. 2017;4:50. https://doi.org/10.3389/fmars 2017.00050.

28. Daniels A, Gutierrez M, Fanjul G, Guerena A, Matheson I, Watkins K. Western Africa's missing fish. The impacts of unreported and unregulated fishing and under-reporting catches by foreign fleets. London: Overseas Development Institute; 2016.

29. Graham J, Johnston WA, Nicholson FJ. Ice in fisheries. FAO technical paper no. 331. Rome, FAO. 1993.

30. Ministry of Fisheries and Aquaculture Development (MoFAD). 2016 Annual report. Accra: MoFAD; 2017, p. 78.

31. GSS. Population and housing census 2010 . Summary report of final results. Accra: Ghana Statistical Service; 2012.

32. FAO. Contribution of fisheries to national economies in West and Central Africa-policies to increase the wealth generated by small-scale fisheries, new directions in fisheries e a series of policy briefs on development issues. Rome: FAO; 2006.

33. Eurostat. Eurostat, conversion factors new, Annex 8 - CF per CN8. 2014.
Ready to submit your research? Choose BMC and benefit from:

- fast, convenient online submission

- thorough peer review by experienced researchers in your field

- rapid publication on acceptance

- support for research data, including large and complex data types

- gold Open Access which fosters wider collaboration and increased citations

- maximum visibility for your research: over 100M website views per year

At BMC, research is always in progress.

Learn more biomedcentral.com/submissions 